\title{
THE ADMINISTRATION AND ENFORCEMENT OF THE FAIR LABOR STANDARDS ACT*
}

\author{
Samule Herman $\dagger$
}

\begin{abstract}
Mr. Woodrum (of Virginia). “ . . As I understand it, Mr. Andrews proposes to speak softly and move cautiously."

Mr. ANDREws (Administrator of the Wage and Hour Division). "Yes, sir."1
\end{abstract}

Twenty-five cents an hour multiplied by 44 hours equals \$Ir.00. In this simple bit of arithmetic may be a key to the startling difference in industry reaction to the administration and enforcement of the Fair Labor Standards $\mathrm{Act}^{2}$ on the one hand and to the National Labor Relations $\mathrm{Act}^{3}$ on the other. Both acts are important elements in the pattern of New Deal labor legislation. One, concerned with voluntary collective bargaining, has been fought unremittingly at all stages and on all fronts. The other, concerned with mandatory labor standards, has been accepted with little or no resistance. In contrast with 25 cents an hour under the Act, the average hourly wage obtained through collective bargaining agreements in the automobile industry was, for the tumultuous "sit-down" first nine months of 1937,88 cents an hour. ${ }^{4}$ Labor cost is an important element in industry acceptance or rejection of administration and enforcement policies in labor legislation. The National Labor Relations Board is in a maelstrom of employer criticism. The same critics, in a sixmonths honeymoon, lauded the Wage and Hour Division. ${ }^{5}$ Is a possible explanation

* The writer gratefully acknowledges invaluable assistance in the gathering of material by Harry $L$. Isikoff, Esq., of the District of Columbia Bar. Needless to say the opinions cxpressed in this article are the writer's own.

+ Ph.B., I929, J.D., x931, University of Chicago. Member of the legal staff, Office of the Solicitor, United States Department of Agriculture. Non-resident Consultant, Graduate School of Public Administration, Harvard University. Member of the Illinois Bar. Contributor to periodicals on economic, legal and political subjects.

${ }^{1}$ Hearings before Subcommittee of the Committce on Appropriations, House of Representatives, on the First Deficiency Appropriation Bill for 1939, 76th Cong., Ist Sess. (1939) 65-66 (hereafter referred to as Hearings on First Deficiency Bill).

${ }^{2} 52$ STAT. 1060 (1938), 29 U. S. C. $\$ \$ 20$ r-2ro (Supp. IV, 1938) (hereafter referred to as the Act.)

${ }^{3} 49$ STAT. 449 (I935), 29 U. S. C. \$\$15I-x66 (Supp. IV, r938).

- United Automobile Workers Research Bulletin No. I (March, 1938). For employec coverage of the Act and average earnings in certain industries see Daugherty, Economic Coverage of the Fair Labor Standards Act, infra, 406, particularly Table 4, p. 413. Cf. Joint Hearings Before Committee on Education and Labor, Senate, and Committee on Labor, House of Representatives, on S. 2475 and H. R. 7200, 75th Cong., Ist Sess. (1937) 338-342 (hereafter referred to as Hearings on S. 2475).

"Indication that the honeymoon may be over is found in the resolution adopted by the United States Chamber of Commerce at Washington, D. C., May 4, 1939, recommending repcal of the Act. N. Y. Times, 
to be found in the fact that on the eve of the effective date of the Act, in no state were the average weekly industrial earnings as low as $\$ r$ r.0o? ${ }^{0}$

The most highly criticized single administrative action of the Wage and Hour Division was the official interpretation that the provision of the Act requiring compensation for overtime in excess of maximum hours "at a rate not less than one and one-half the regular rate at which employed" extended to all employees whatever paid. ${ }^{7}$ The interpretation urged upon the Wage and Hour Division was that the overtime provision applied only to employees paid the basic minimum wage rate. On the basis of a 44 -hour week and 22 hours overtime an employee earning \$roo per week would be entitled to \$I75; an employee earning the minimum would be entitled to $\$$ I9.25. At the opening of the first session of the 76 th Congress, Administrator Andrews announced his approval of an amendment to the Act which would exempt employees on a monthly basis or a guaranteed monthly salary of $\$ 200$ or more. ${ }^{8}$ Requests to Congress by the responsible administrative agency that the applicability of the statute administered be curtailed are rare. Restrictive amendment as administrative policy must have compelling reasons. Some of these reasons will be considered herein.

Simple arithmetic also acts as framework for, and has a large part in determining, the problems and policies of administration and enforcement. As more employees are brought within the Act by the escalator wage and hour clause, more problems of interpretation and administration will arise. ${ }^{9}$ Attempted enforcement will meet greater resistance from employers of labor in the higher wage categories. Of regulatory statutes since 1933 , none has a greater range of applicability, ${ }^{10}$ none is so

May 5, 1939, p. I, col. 4. Possible explanations: (I) three industry committees have recommended wage rates above $25 \mathrm{c}$ an hour; hosiery, $40 \mathrm{c}$ and $321 / 2 \mathrm{c}$, (1939) 2 WAGE \& HouR REP. I66; woolen, $36 \mathrm{c}, 2$ id. I15-II6; textile, $32 \frac{1}{2} \mathrm{c}$ without differential, 2 id. 155-156; (2) October 24, 1939, when the minimum rate becomes $30 c$, is drawing rapidly near; (3) criminal prosecutions have resulted in heavy fines, see note II 4 , infra; (4) consent decrees have been conditioned upon restitution to employees, ibid; (5) the "hot goods" provision has been effectively invoked, see note $\mathrm{r}_{23}$, infra.

${ }^{\circ}$ From compilation prepared by Commissioner Lubin, Bureau of Labor Statistics, U. S. Department of Labor, and contained in press release issued by Wage and Hour Division, October 31 , 1938. In Wyoming, for August 1938 , in manufacturing industries, the average weekly earnings were $\$ 32.16$; in Michigan, \$30.00; in New York, \$25.51. Lowest were Georgia, \$13.71, Mississippi, \$14.16. From the employee's point of view, the average weekly earnings in any state may mean nothing, if he himself earns less than the average.

"Interpr. Bull. No. 4, Oct. 2r, 1938. The Administrator announced on October 17,1938 , that, in his opinion, the Act did not require payment of overtime rates to salaried employees. (I938) I WAGE \& HouR REP. I. Interpretative Bulletin No. 4, issued Oct. $2 \mathrm{I}$, I938, officially reversed this interpretation. Cf. interpretation of National Association of Manufacturers, (1938) I WAGE \& HoUR REP. 355-357.

${ }^{8}$ See (1939) 2 WAGE \& Hour REP. 3-4; see also page 389, infra.

- Sce Cooper, The Coverage of the Fair Labor Standards Act and Other Problems in Its Interpretation, supra, p. 333 .

10 Applicability of NIRA was, of course, greater but overextension was one of the grounds of its eventual invalidation. According to estimates of the Division of Economic Research and Planning of NRA, the NRA codes had a potential coverage of approximately $27,000,000$ workers, on the basis of I929 employment figures. As of January I, I935, approximately 89 percent of the possible coverage had actually been attained. The actual number of employees under NRA codes ran over 22,000,000. By August I934, 22,022,000 employees were distributed among 517 codes. See Marshall, Hours and Wages Provisions in NRA CODEs (Brookings Institution, 1935) 3, 4. 
dependent for the successful realization of the policy objectives of Congress upon the policy of administration and enforcement.

But the policy of Congress as expressed in the findings and declaration of policy of the Act and the policy of Congress relative to the functioning of the Wage and Hour Division were, in the beginning, not quite the same. Congress found that there were labor conditions "detrimental to the maintenance of the minimum standard of living necessary for health, efficiency and general well-being of workers,"11 and tersely described the serious national effects of such conditions. It declared its policy to be ". . . to correct and as rapidly as practicable to eliminate the conditions above referred to in such industries without substantially curtailing employment or earning power."12 The Act was passed after one of the hardest fought legislative campaigns in New Deal history. ${ }^{13}$ Congress, through its exercise of the appropriation power, immediately assumed control of the tempo of correction and elimination of unfair labor conditions. $\$ 500,000$ was asked. ${ }^{14} \$ 400,000$ was appropriated for the fiscal year ending June 30, I939; of this, $\$ 50,000$ was allocated by the Department of Labor to the Children's Bureau. ${ }^{15}$ It was immediately apparent that effective administration and enforcement would be greatly hampered. By January 1939, the Wage and Hour Division operated on a skeleton staff with borrowed personnel, ${ }^{10}$ had 75 field inspectors, ${ }^{17}$ having started with 23 (as contrasted with a conservatively estimated need for $603^{18}$ ), had been unable to establish even a remotely adequate organization, ${ }^{10}$ functioned at great overtime pressure upon its own personnel in Washington. ${ }^{20}$ From this point of view, the interim report of the Administrator to Congress was largely an apologia. ${ }^{21}$ There had been no money.

A deficiency appropriation was sought. The Wage and Hour Division asked $\$ 1,350,000 .^{22}$ The Bureau of the Budget allocated $\$ 950,000 .^{23}$ The First Deficiency Appropriation Act, fiscal year I939, effective March I5, I939, appropriated $\$ 850,000$, available for the balance of the fiscal year I939. ${ }^{24}$ The $\$ 850,000$ was earmarked by Congress to include "reimbursement to State, Federal and local agencies and their employees for services rendered" and was available to pay for administrative expenses theretofore accrued.
$11 \S_{2}(\mathrm{a})$.
$12 \S_{2}(\mathrm{~b})$.
${ }^{13}$ See Forsythe, Legislative History of the Fair Labor Standards Act, infra, p. 464.

14 Budget estimates submitted by the President. SEN. Doc. No. 226, 75th Cong., 3d Sess (1938) 1069. See N. Y. Times, June I7, I938, p. I, col. 7 .

${ }_{16}$ Second Deficiency Appropriation Act, fiscal year 1938, Pub. L. No. 723, 75th Cong., 3d Sess., approved June 25, 1938. It will be noted that the Deficiency Act and the Fair Labor Standards Act were approved on the same day. The $\$ 400,000$ was "to carry into effect the provisions of the Fair Labor Standards Act of 1938 " including the functions of the Children's Bureau under the Act.
${ }^{10}$ Hearings on Deficiency Bill, 83 .
is $I d$. at 56 .
${ }^{17}$ Id. at 77 .

20 Id. at 95. Testimony of the Administrator: "We have a tremendous amount of overtime. We have to work two shifts, the space is limited. 'We not only work two shifts, but we have a sort of shift and a half that works in the halls of the building, because we have not the space at the present time to get out all the stuff that we should."

${ }^{21}$ Administrator's Annual Report to Congress, for the period Aug. 15 to Dec. 21, 1938, relcased to the press on January 16, rg39.
${ }_{22}$ Hearings on Deficiency Bill, 73 .
${ }^{28}$ Ibid.
24 Pub. L. No. 7, 76th Cong., Ist Sess., approved March 15, I939. 
By middle January, r939, the total personnel of the Wage and Hour Division numbered 488, of which IIr were on loan from other agencies and not compensated from Wage and Hour Division funds. There were 18 lawyers, two borrowed from other agencies; I5 $_{5}$ administrative employees in the Cooperation and Enforcement branch; 25 in the Wage and Hour Standard branch. ${ }^{25}$ Of the 488 employees, Ir3 were in the field, distributed as between $I_{3}$ field office staffs. Based upon the request for $\$ 950,000$, the personnel of the Wage and Hour Division would number 754 including 248 inspectors. Estimates for the fiscal year I940 call for 966 employees, 343 to be inspectors. ${ }^{26}$

To a great extent the ability to administer and enforce an act of this nature is dependent upon adequate personnel. Control by Congress may be indirect as well as direct. It may be by malnutrition through withholding of necessary funds, as well as by curtailment or expansion of powers through the formal process of amendment. Thus subject to the will of Congress, what, in brief, are the powers of the Administrator? What are the basic administrative problems arising out of the Act, the administrative policy in connection with the problems, the administrative set-up to accomplish the policy?

The substantive provisions of the Act are limited in number and simple in content. $^{27}$ The labor standards involved pertain, basically, to certain aspects of interstate commerce in goods. They affect the employment relationship, in respect to wages and hours of employees who are either engaged in interstate commerce or in the production of goods for interstate commerce. ${ }^{28}$ A minimum wage of not less than 25 cents an hour is prescribed by the Act for the first year after its effective date and, thereafter, a sliding scale is provided, resulting in a minimum of not more than 40 cents an hour after the expiration of the seventh year. ${ }^{29}$ The wage rates may, however, be increased above the minimum rate established by the Act (but not in excess of 40 cents an hour) by wage order promulgated by the Administrator, in accordance with a procedure relating to the appointment and functioning of industry committees. $^{30}$ Wage orders are an administrative device whereby applicability of the Act may be quickened.

${ }^{25}$ All data from Hearings on Deficiency Bill, 77-83.

${ }^{20} I d$. at 77 . Estimates of the completed staff of the Wage and Hour Division place the number at approximately I500. Id. at 55. Before his appointment as Administrator, Mr. Andrews presided as New York State Industrial Commissioner over 7200 employees. Id. at 69 . To administer the New York State minimum wage law, Mr. Andrews had over 360 inspectors, one to every 2500 covered employees. Id. at 56. Cf. Johnson, The Administration of Minimum Wage Laws in the United States (I939) 39 INT. LAB. REv. I7I.

${ }^{27}$ Paradoxically, this very simplicity has created problems of interpretation and administration which enactment of the more detailed bill, as originally introduced, would probably have obviated. Adoption of the final simplification was on the ground, among others, that the proposed bill was too complicated to administer. Cf. Hearings on $S .2475,579,622,645,649,753,815$; N. Y. Times, June 12, 1937, p. 2, col. 2, July 2, x937, p. 26, col. 3. Yet numerous administrative devices designed to aid in administration and enforcement were eliminated in Congress prior to enactment, notably, as will be seen, an administrative rule-making power.

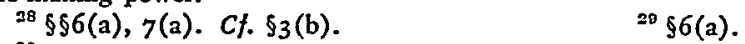

${ }^{30} \$ 8$. See Dickinson, The Organization and Functioning of Industry Committees under the Fair Labor Standards Act, supra, p. 353. 
As to hours, there is an outright prohibition against employment in excess of a work-week which, during the first year, is 44 hours and after the expiration of the second year is 40 hours, unless the employee is compensated for his employment in excess of the hours specified "at a rate not less than one and one-half times the regular rate at which he is employed." 31 Exception is made in the case of specified collective bargaining agreements or, for designated periods of time, in the case of industries of a seasonal nature. ${ }^{32}$ Provision is made for exemption from the maximum hours provision for a period, or periods, of not more than 14 work-weeks in any calendar year, of certain types of employment involved in the processing of agricultural products. ${ }^{33}$

Complete exemption as to both wage and hour standards or hour maxima alone is allowed as to various categories of employment ${ }^{34}$ and a special certificate procedure permitting sub-standard minimum wages, subject to limitations prescribed by the Administrator as to "time, number, proportion and length of service," is provided for learners, apprentices, messengers and handicapped workers. ${ }^{85}$

The child labor ${ }^{36}$ provision of the Act prohibits outright the shipment, or delivery for shipment, in interstate commerce, of "any goods produced in an establishment situated in the United States in or about which within thirty days prior to the removal of such goods therefrom any oppressive child labor is employed,"37 but children employed in agriculture or as actors in motion pictures or theatrical productions are exempt. ${ }^{38}$

The fundamental administrative problems in connection with the Act are similar in principle to those found in other New Deal regulatory legislation. Essentially, the problems are in law and economics and lie between two poles. The first is the desirability of fixing in law a positive formulation to guide and control administration and to provide a basic certainty as to the effect of the legislation on industry and employees; the second is the need for flexibility in meeting specific industrial situations in terms of changing economic factors unpredictable at the time of enactment. The primary administrative problem of the Wage and Hour Division may be put as follows: In an act designed to increase employment and purchasing power of employees, will the establishment of fixed levels of minimum wages above and maximum hours below the current industrial levels curtail rather than increase employment? If an act designed to increase employment would, in net effect, decrease employment, it would more than fail to accomplish its objective; it would aggravate and foster the very evil intended to be remedied. Since the effect of wage and hour regulation upon employment and unemployment was extensively debated in Congress, it is apparent that the issue was finally referred, in part, from the legislative to the administrative process. Section 8 of the Act, providing for wage orders to be

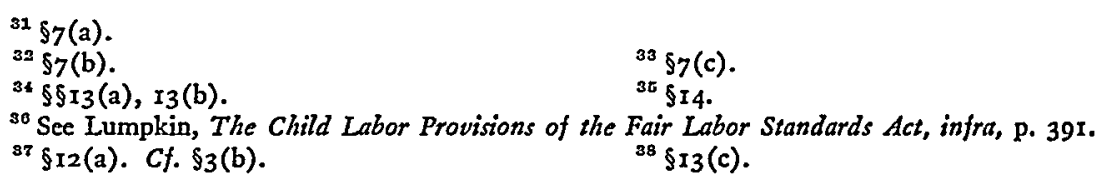


issued industry by industry, represents the dilemma of the legislative process in meeting problems of modern economy too subtle and complex to be solved by legislative statement. The exemption provision of the Act also centers upon the problem of unemployment, since discretion is conferred upon the Administrator to grant or refuse certain exemptions, a discretion conditioned upon the effect of mandatory labor standards on employment.

Other problems were removed from the process of administrative determination by outright prohibition. Thus, no sex classifications were permitted in the matter of wages and hours, although the applicability of wage and hour legislation to men represented a departure from prior, and by now traditional, state legislation applicable only to women and minors. ${ }^{39}$ The matter of the effect of the Act upon unions was resolved by excepting from maximum hour provisions certain hour arrangements arrived at through collective bargaining. ${ }^{40}$ The area of administrative action, although circumscribed by the specific provisions of the Congress, was not entirely clarified. Compromise statutory solutions necessitated administrative interpretation.

To deal with these and other important administrative problems, the Wage and Hour Division was set up as a semi-autonomous agency within the Department of Labor, the Act providing for appointment of an administrator to direct a Wage and Hour Division. ${ }^{41}$ The Secretary of Labor could thus coordinate the broad policies of the Wage and Hour Division and of the Department of Labor. Since the administration of the child labor provisions of the Act had been placed within the jurisdiction of the Children's Bureau, ${ }^{42}$ and since the Bureau of Labor Statistics had supplied, and would continue to supply, needed data for the administration of the Act, ${ }^{43}$ the creation of a Division within the Department seemed justified. Duplication and unnecessary expense were avoided by utilizing the budgeting, personnel, and supplies facilities of the Department. ${ }^{44}$ Liaison activities with the states for the purposes of assuring cooperation in enforcement, conference with state labor officials, preparation of model state minimum wage and labor legislation, were aided by the long-time experience of the Department. The original appropriation for the Wage and Hour

${ }^{30} \$ 8(\mathrm{c})$. See de Vyver, Regulation of Wages and Hours Frior to 1938 , supra, p. 323. For a discussion of the due process features of a recent Oklahoma minimum wage law applicable to men, as well as to women and children (Okla. Laws, I936-I937, c. 52), see Associated Industries of Okla. v. Industrial Welfare Commission, 90 P. (2d) 899 (I939).

${ }^{10}{ }_{7}(\mathrm{~b})$.

$12 \$_{4}(\mathrm{a})$. The bill originally introduced had provided for the creation of a labor standards board to be composed of five members with staggered terms. \$3(a). The labor standards board was to exercise the quasi-judicial and quasi-legislative functions in the field of fair labor standards customarily exercised, with due regard to the particular type of regulation involved, by independent regulatory commissions. The President's Committee on Administrative Management has referred to independent commissions as the "headless 'fourth branch' of the Government, a haphazard deposit of irresponsible agencies and uncoordinated powers." Administrative MaNagement of the Executive Branch of the UNited States (1937).

${ }^{3} \S_{12}(\mathrm{~b}) . C f . \S_{3}(\mathrm{I}), \operatorname{Ir}(\mathrm{b})$.

${ }^{4}$ \$150,000 of the deficiency appropriation for the balance of the fiscal year, ending June 30, r939 (see note 24, supra) was intended to be transferred to the Bureau of Labor Statistics for special studies in connection with garment and boot and shoe industries. Hearings on Deficiency Bill, 67 .

"Id. at 84 . 
Division was within the Department of Labor appropriation and under the direction and control of the Secretary of Labor. ${ }^{45}$

The present organization of the Wage and Hour Division follows conventional lines established in governmental units administered by a single administrator. ${ }^{40}$ General supervisory activity and legal responsibility for the administration of the Act is vested in the Administrator. Closely connected with the Office of the Administrator is the Office of the Deputy Administrator. Responsible for efficient administration and coordination of the activity of the Division, the Office of the Deputy Administrator assists in the development of the organization and procedures of the Division, prepares instructions, reviews regulations, orders, correspondence and forms, and serves as liaison with other agencies. Industry committees are coordinated through the Office of the Deputy Administrator.

Functionally, there are three main branches in the Wage and Hour Division: Legal, Wage and Hour Standards, and Cooperation and Enforcement. ${ }^{47}$ The two latter are under the direction of Assistant Administrators.

The Office of the General Counsel is responsible for all legal activities of the Division, and, when completely established, will have three sections. At present there are two main sections, Opinion and Litigation. A Wage Hearing Section is being slowly built up. (a) The Opinion Section drafts regulations and administrative orders, reviews hearings held by the Administrator or his representatives, and drafts findings and orders for the Administrator. It is responsible for the preparation of legal interpretations and formal legal opinions, and the drafting of legislative proposals. (b) The Litigation Section represents the Administrator in civil litigation growing out of the Act, and, as will be seen, has primary responsibility for appearing in the courts on behalf of the Administrator in injunction and other civil proceedings. It recommends criminal prosecutions to the Department of Justice. In general, it advises the Cooperation and Enforcement branch on enforcement problems. A liaison attorney has been assigned to the Cooperation and Enforcement branch for the purpose of reviewing complaints to determine whether they contain the necessary legal prerequisites to allow recommendations for court action. ${ }^{48}$

The Wage and Hour Standards branch is responsible for the arrangements and functioning of industry committees, the collection and analysis of economic data, and the granting of exemptions. It is divided into an Industry Committee Section, a Hearing and Exemption Section, and an Economic Section. The Industry Com-

\footnotetext{
¿5 The appropriation was to meet a Department of Labor deficiency. See note 14, stlpra.

${ }^{16}$ Information as to the organization of the Wage and Hour Division is in part based on interviews at the Wage and Hour Division, in part on a functional chart approved by the Administrator, Jan. 6, I939.

${ }^{4}$ A Business Management branch has personnel, fiscal and training sections. An Information branch has press, editorial, magazine, labor and trade papers and radio sections.

${ }^{48}$ Regional attorneys will be provided for regional offices when, and as, established to render advice on questions of law involved in enforcement, to answer legal inquiries and to assist in litigation growing out of violations of the Act. As all-industry committees are designated, the legal branch furnishes a legal advisor to such committee to assist in the presentation of the evidence upon which the Administrator issues a wage order. The advisor confers with the Industry Committee section of the Wage and Hour Standards branch on legal questions.
} 
mittee Section assists in the selection of industry committees, defines their jurisdiction and establishes rules and procedure. It serves as liaison between industry committees and other governmental agencies and assists the committees in completing their tasks.

The Hearing and Exemption Section conducts hearings, on request, to define "seasonal industry" and "area of production," and recommends the granting or refusal of applications for exemptions under Section I4 for learners, handicapped workers, apprentices and messengers. It is also charged with handling the great number of requests currently arriving at the Division for modification of regulations. The Economic Section compiles and analyses economic data, advises the Administrator on the recommendations of industry committees, and serves as economic advisor to all branches of the Division.

The Cooperation and Enforcement branch is responsible for the regional field activities relating to cooperation and enforcement, participates in the development of enforcement policies and procedure, and in the establishment of cooperative agreements with the states. It is divided into a Field Operations Section, a Policy and Standards Section, and a Regional and Field Office Section. The Field Operations Section arranges and supervises regional and field enforcement activities of the Division; serves as liaison with the regional offices and clears all matters going to and coming from the field. The Policy and Standards Section develops basic standards for cooperative agreements with the states and formulates basic procedure in field operations; examines violations referred to Washington and reviews reports from regional and field offices; and maintains a current review of enforcement activities. The Regional and Field Offices Section is responsible for the successful administration of the Act in the regions; for direction and supervision of the field instruction staff and for relations with cooperating state agencies. It makes inspections and investigations necessary for enforcement, and aids employers and employees in understanding the terms of the Act.

As of April, 1939, there were four regional offices of the Wage and Hour Division: Boston, New York, Cleveland, San Francisco. ${ }^{49}$ As distinguished from regional offices, there were twenty-six field offices located wherever space could be rendered available in the field by existing governmental agencies. Field offices are usually located in offices of the Social Security Board and the National Emergency Council, ${ }^{50}$ and serve as central points for inspectors and as information centers. Plans for the regional offices, at present greatly understaffed, provide that each office be manned by a regional director, a supervising inspector, an attorney, an enforcement representative, a senior inspector, inspectors, and a clerical staff.51 Present organization plans contemplate twelve regional offices and seventy-six field offices to be established within the fiscal year ending June 30 , 1940.52

An important phase of Wage and Hour Division policy relates to other agencies of the Government, to state labor departments and officials, and to labor unions and

\footnotetext{
${ }^{10}$ Information obtained from Wage and Hour Division. Cf. (1939) 2 WAGE \& Hour Rep. 26-27.

${ }^{\circ}$ Hearings on Deficiency Bill, 57 .

EI Id. at 82 .

${ }^{52} I d$. at $83-84$.
} 
trade associations. The range of its regulatory activity, together with the limited resources of the Wage and Hour Division, would make adequate administration impractical, if not virtually impossible, without the aid of outside sources. The United States Department of Labor participates actively, on various fronts, to aid in the administration of the Act. ${ }^{53}$ Legislative strategy attempting to isolate the Wage and Hour Division by placing control over appropriations to the Division in the Administrator rather than in the Secretary of Labor seems to have failed in the first session of the 76 th Congress. Press reports indicate a modus vivendi established between the Administrator and the Secretary of Labor. ${ }^{54}$

Collaboration of the Wage and Hour Division and the Department of Justice is dependent upon an obscure provision of the Act relating to the bringing of legal action. Section $\operatorname{Ir}(\mathrm{a})$ provides in part:

“... the Administrator shall bring all actions under Section 17 to restrain violations of this Act."

Section 4 (b) contains, inter alia, the following language:

"Attorneys appointed under this section may appear for and represent the Administrator in any litigation, but all such litigation shall be subject to the direction and control of the Attorney General."

The meaning of "subject to the direction and control of the Attorney General," in the light of Section II(a), is obscure. As a matter of administrative practice a division of function has been arrived at by the Wage and Hour Division and the Department of Justice. The latter, through a Wage and Hour unit of the Anti-Trust Division, especially created for the purposes of litigation under the Act, and at present staffed by thirteen attorneys, ${ }^{55}$ is in full charge of criminal prosecution of complaints referred to it by the Wage and Hour Division. Matters of civil injunction are handled exclusively in the lower courts by the Wage and Hour Division.

The Act authorizes the Administrator to utilize the services of state and local agencies in connection with administration and enforcement and to reimburse them for services rendered. ${ }^{56}$ Because state inspectors are familiar with industrial problems, and because of the lack of funds to hire and train an adequate number of federal inspectors, reliance, in some measure, must be put in state facilities. Cooperation is

\footnotetext{
Es The Bureau of Labor Statistics has been at all times, and continues to be, a fount of information for the Wage and Hour Division. See note 43 , supra. Data adduced by the Bureau at the legislative hearings indicated the economic importance of the bill. Hearings on $S$. 2475, 309-363. Payroll data essential for wage determination and for other phases of the administration of the Act, particularly in regard to the establishment and functioning of industry committecs, have been obtained largely from the Bureau. Matters of economic incidence and economic policy standards are determined largely from data assembled at the Bureau. See Daugherty, infra, 406. The Children's Bureau, in addition to administering the provisions relative to child labor, makes investigations and inspections with respect to the employment of minors, and brings legal action to enjoin unlawful child labor practices. \$12(b). The Department is required by the Act to furnish, through its burcaus and divisions, the investigations and inspections essential to the gathering of data regarding wages, hours, and other conditions and practices of employment. $\$ I I(a)$.

5* Wash. Daily News, April 24, 1939, p. ro, col. r.

${ }^{55}$ (1938) I WaGe \& HOUR ReP. 402.
} 
furthered by forwarding complaints received by the Wage and Hour Division, indicating violation of a state law, to the state and receiving from the state complaints indicating federal violation. ${ }^{57}$ Minimum enforcement needs, under present conditions, require reliance upon state experience and facilities. The long-time advantage of too great reliance upon decentralized and non-responsible inspection of interstate commerce by state inspectors may be seriously questioned. That a striking variation exists in the vigor and quality. of state inspection and enforcement is well known. ${ }^{58}$

Labor unions play an important part in policing the Act ${ }^{59}$ and are destined to play an even greater part. They have not overlooked the importance of the Act for organizational purposes. On October 25, 1938, in a letter addressed by the President of the AFL to all affiliated unions, he stated: "The Wage and Hour law was enacted by Congress mainly as a result of the demand for this legislation by officers and members of the American Federation of Labor." ${ }^{\circ 0}$ Subsequently, the AFL announced that wage and hour committees had been established in 520 communities and that committees were being established in 300 additional cities for the purpose of facilitating the routing of complaints, the conduct of educational work as to the meaning and purpose of the Act, and precaution against precipitate litigation by employees which might endanger the Act in the courts. ${ }^{11}$ The $\mathrm{CIO}$ vied for credit, announcing: "The enactment of this law was due in large part to the efforts of the CIO."62 The CIO established a central complaint bureau. ${ }^{63}$

Trade associations, through trade papers, meetings, and other means, have counseled their members how best to comply with the Act. Avoidance of the law and pressure to amend, rather than evasion, has been the motif of trade association advice. ${ }^{64}$ As groups, they have urged interpretations which would restrict applicability and have endeavored to avail themselves of the numerous opportunities afforded in the regulations for hearings upon exemptions and definitions. ${ }^{65}$ Both unions and trade associations have policed the Act, each active in their respective interests. The movement of interpretation and public information by the Wage and Hour Division, as judged by the first six months of administration and enforcement, may be fairly

\footnotetext{
${ }^{67}$ From address delivered by Administrator Andrews at the Fifth National Conference on Labor Legislation at Washington, D. C., Nov. 16, 1938.

${ }^{68}$ By April 15, 1939, enabling legislation permitting state labor departments to cooperate with the Wage and Hour Division in the administration and enforcement of the Act and to receive financial reimbursement therefor had been enacted by California, Montana, Oregon, North Carolina, South Carolina and Vermont.

${ }^{50}$ Both the AFL and the CIO have established complaint procedures paralleling the complaint procedure of the Wage and Hour Division. See page 384 , infra.

${ }^{\circ 0}$ Statement in letter enclosing affidavit form on which violations of the Act could be reported, the affidavit to "serve as a basis for the enforcement of the provisions of the Act." Cf. (1938) I WAGE \& Hour Rep. 68.

${ }^{01}$ Ibid.

-2 Your Rights Under the Federal Wage-Hour Laws, CIO, Publication No. 29, April, 1939, p. 2.

${ }^{23}$ No local wage and hour groups were established by the CIO. 'TWOC, a CIO agency, established a Wage and Hour Bureau to render advice upon complaints and to forward such complaints to the Wage and Hour Division when justified. Op. cit. stupra, note 62; cf. (1938) I WAGE \& Hour REP. 67. In April 1939, the TWOC bureau became the official Wage and Hour clearing house for CIO organizations.

ol Cf. (I938) I WAGE \& Hour Rep. 403-404. ${ }^{66}$ See pp. 380-38I, infra.
} 
interpreted to be in the direction of conciliation and assuasion of trade association and other employer groups. ${ }^{86}$

Enforcement, as a phase of the administrative process, commences first with clarification of the meaning of legislation. ${ }^{67}$ Apart from the serious limitation placed upon administration and enforcement by the restricted appropriations of an economyminded Congress, perhaps the outstanding difficulty, from the point of view of employer compliance, has been the lack of an administrative rule-making power. The multifold and multiform activities of American industry inevitably necessitated numerous specific administrative rulings as to applicability and construction of the statute. Questions of interpretation were, and are, numerous and vexatious. Because the actualities of economics are neither state nor federal, the motivation of industrial organization and form cannot, in most cases, be laid to an adjustment to the latest interstate categories established by the Supreme Court of the United States. In the circumstances of the passage of the Act, industry was sensitized to wages and hours in terms of specific operational problems involved. Trade associations, labor unions, the general and trade press, emphasized the practical effect of the Act upon the operation of business and the compensation of employees. The Wage and Hour Division was immediately flooded with requests stating typical operational factors in given business activities and requesting authoritative rulings as to the applicability of the Act. ${ }^{68}$ The hundred-and-twenty-day period between enactment and effective date of the wage, hour and child labor provisions of the Act ${ }^{69}$ permitted industry to reflect as to whether or not a particular business was affected and whether readjustments in terms of personnel and price policies ought to be made. In November 1938, the Office of the General Counsel of the Wage and Hour Division commenced the issuance of a series of interpretative bulletins. By early May, 1939, thirteen such bulletins had been issued. As will be seen, these interpretative bulletins are innovations under regulatory acts and have characteristic qualities directed largely to moral suasion of employers.

A rule-making power had been contained in the Act as originally introduced.70 The issuance of "interpretative bulletins" by the Wage and Hour Division stemmed from the failure of Congress to include a rule-making provision in the Act. The

\footnotetext{
${ }^{\circ 0}$ By May 7, 1939, twenty-six formal released addresses had been delivered by Wage and Hour Division administrative officials to employer groups; two to employee groups.

${ }^{67}$ In contradistinction to such well-established administrative agencies as FTC and ICC, and to such relatively new agencies as NLRB and SEC, all enforcement of the Act is in the courts. The issuance of administrative orders upon cease and desist theory is not permitted by the Act. If such were the case, judicial enforcement, as a general rule, would be by review rather than de novo. Every act of enforcement must be litigated under the Act. The Act does not provide for an administrative hearing to determine if there has been violation. Cf. $\$ I(c)$ of the Agricultural Marketing Agrcement Act of 1937, reenacting $\$ 8 \mathrm{a}(7)$ of the Agricultural Adjustment Act, as amended. Investigation must therefore be catch-as-catch can; hence the complaint and inspection policy of the Wage and Hour Division. Sce page 384 , infra.

${ }^{\text {es }}$ Testimony of the Administrator: "When I arrived on the job there were about 10 or 11 thousand letters, and they are still coming in at about 7,000 a week." Hearings on Deficiency Bill, 92.

o $\$ \S 6(b), 7(d), 12(a)$.

${ }^{70}$ \$6. This provision was broader than a similar rule-making power proposed as amendment to the Act in $\$ 4(d)$, H. R. 5435,76 th Cong., Ist Sess. (1939). See page 389 , infra.
} 
bulletins were the creature of necessity. The power of the Administrator to issue binding and authoritative regulations is confined to specific provisions of the Act. They are of legal necessity limited in scope. The interpretative bulletins devised by the Wage and Hour Division are self-denying as witnessed by the following typical statement:

"... interpretations announced by the Administrator, except in certain specific instances where the statute directs the Administrator to make various regulations and definitions, serve only to indicate the construction of the law which will guide the Administrator in the performance of his administrative duties, unless he is directed otherwise by the authoritative rulings of the courts, or unless he shall subsequently decide that a prior interpretation is incorrect." 71

Rule making so severely restricted is, in view of the industrial need for certainty, meeting Goliath with a sling shot, a romantic but risky business.

The interpretative bulletins are not binding on industry; they are merely legal advice-good, perhaps the best. While industry is advised to comply, if in doubt, ${ }^{\mathbf{2}}$ the employer is not immune if, in reliance upon an interpretative bulletin, he concludes that the Act is not applicable to him. He may be subsequently prosecuted under Section $16(\mathrm{a})$, sued by an employee under Section $16(\mathrm{~b})$, or enjoined under Section $\mathrm{r} 7$. If, in reliance upon the interpretation, he complies and his competitor does not, and it is judicially established that the interpretation of his competitor was correct and that of the Wage and Hour Division incorrect, he is placed at a material competitive disadvantage assuaged only by his conscience in having relied upon the Wage and Hour Division interpretation. Conscience, under these circumstances, is small compensation in modern, competitive business practice, particularly that of marginal business primarily affected by the Act. The lack of uniformity, the uncertainty, the need for reliance upon advice of private counsel as to whether or not to accept the view of the Wage and Hour Division is, from the point of view of the employer, an obvious lacuna in the enforcement of the Act. ${ }^{73}$

The interpretative bulletins issued by the Office of the General Counsel ${ }^{74}$ may be

${ }^{71}$ Cf. Interpr. Bull. No. I, Oct. I2, 1938.

72 "When in doubt, comply" has been the motif of answers by the General Counsel to enquiring employers. See speech by Administrator Andrews before American Association for Labor Legislation, Detroit, Michigan, December 29, 1938; Cf. Andrews, Making the Wage-Hour Law Work (I939) 29 AM. LAB. LEg. Rev. 53, 59.

${ }^{73}$ From the point of view of the employee the advantages of a rule-making power are not apparent. Under the rule-making power proposed (see note 70 , supra), the employer, if he relies in good faith on the Administrator's interpretation of the law, will be immune from civil suit by an employec. The employer could also disregard the rule and challenge it in the courts. If the employee successfully challenges the rule, the employer would still be immune. See $\$ 4(d), H$. R. 5435, 76th Cong. Ist Sess. (I939). Much depends on the nature of the rules. The interpretative bulletins have, in general, construed the Act broadly to protect the employee. If the rules should become narrow and restrictive, the employee would not be benefited by a rule-making power. He would be effectively deprived of the benefits of the double indemnity remedy. One may speculate on the relative advantages of a rule-making power to (I) employers and (2) employces where there is (a) a sympathetic administrator and an unsympathetic court; (b) an unsympathetic administrator and a sympathetic court.

${ }^{74}$ As of May 3, 1939, they are as follows: No. 1, General Statement as to the Coverage of the Act; No. 2, Application of the Act to the District of Columbia and Territories and Possessions; No. 3, General Statement as to the Method of Payment under the Act, and the Application of Section $3(\mathrm{~m})$ thereto; No. 4, 
best described as legal essays in statutory construction. Except that they do not discuss actual fact situations presented for legal opinion, they are the type of legal discussion customarily prepared by legal staffs of administrative agencies to guide administrative officials in the performance of their statutory duties. Such opinions have little binding effect upon either third persons or courts. ${ }^{75}$ They aid in the establishing of administrative practice within the agencies and are given such binding effect as responsible administrative officials allow. The interpretative bulletins state hypothetical rather than actual cases. They attempt to achieve binding effect by persuasive reasoning, simple phrasing, and relative informality. They are based upon legal prophecy as to what the courts will do.

There is no attempt to support analyses by legal citation, although frequent reference is made to the legislative history of the Act. While the bulletins attempt to speak accurately, there is a minimum of technicality. It is apparent that they are designed for laymen as well as lawyers. A continuity is established by cross reference from later to prior bulletins. The bulletins are interesting adventures in legal persuasion. Legal staffs of administrative agencies customarily advise, guide and persuade administrative officials by interpretative writings. Legal staffs also prepare legal writings to persuade themselves of the propriety of contemplated legal action. These bulletins attempt to persuade the public.

In eight different instances in the Act, the Administrator is empowered to prescribe rules and regulations. ${ }^{76}$ These mandatory regulatory functions are of two kinds: procedural rules, such as regulations relating to the functioning of industry committees and the keeping of records; substantive rules, implementing and completing broad statutory principles. In connection with regulations upon such compli-

Maximum Hours and Overtime Compensation; No. 5, Further Statements as to Coverage of the Act: No. 6, The Scope and Applicability of the Exemptions provided by Section 13(a) of the Act; No. 7, Forestry or Lumber Operations Incident or in Conjunction with Farm Operations; No. 8, Collective Bargaining Agreements under Section $7(b) I$ and Section $7(b) 2$ of the Act; No. 9, The Scope and Applicability of the Exemptions provided by Section $13(b)$ I of the Act; No. I0, Farmers' Cooperative Associations under the Act; No. II, The Scope and Applicability of the Exemptions Provided by Section I3(a)(3) of the Act; No. 12, The Scope and Applicability of the Exemptions Provided by Section 13(a)(5) of the Act; No. 13, Determinations of Hours for Which Employees are Entitled to Compensation under the Act.

${ }^{25}$ Some weight is given by the courts to contemporancous and practical construction put upon a statute by executive officers if rights have accrued by reason of reliance upon the construction. If the construction is doubtful, it will be usually disregarded. Quaere whether the interpretative bulletins fall within the rule. See Studebaker v. Perry, I84 U. S. 258, 268, 269 (I902); of. New Haven R. R. Co. v. Interstate Commerce Commission, 200 U. S. 36r, $40 x, 402$ (I906).

${ }^{76} \S_{3}(\mathrm{~m}), 5(\mathrm{c}), 7(\mathrm{~b}), 7(\mathrm{c}), \mathrm{II}(\mathrm{c}), \mathrm{I}_{3}(\mathrm{a}), \mathrm{I}_{4}$. As of this writing, the regulations are: industry committees, 29 CODE FED. REG., c. 5, pt. 5xx, 3 FED. REG. 2744 (1938); references hereafter in this note are, first, to the above title and chapter of the Code of Federal Regulations and, second, to the Federal Register; records to be kept by employers, pt. 516, p. 2533 (I938); employment of apprentices, pt. 521, p. 2483 (1938); employment of learners, pt. 522, p. 2484 (1938); employment of messengers, pt. 523, p. 2485 (1938); employment of handicapped persons, pt. 524, p. 2485, amended Jan. 31, 1939, 4 FED. REo. 485 (1939) and March 22, 1939, id. at 1342; industries of a seasonal nature, pt. 526, p. 2534 (1938), amended, Dec. 20, x938, 3 id. at $3 \mathrm{r27}$; reasonable cost of board, lodging, and other facilities, pt. 531, p. 2535 (1938); defining the term "area of production," pt. 536, p. 2536 (1938), amended Dec. 24, 1938, id. at 3072 and Feb. 23, 1939, 4 id. at 1009 (1939); defining and delimiting the terms "any cmployee employed in a bona fide executive, administrative, professional, or local retailing capacity, or in the capacity of outside salesman," pt. 54I, p. 2518 (1938). 
cated matters as determination of "reasonable cost" or definitions of "seasonal nature" or "area of production," administrative devices have been designed to permit adequate application of general legislative concepts to particular situations, to substitute pedestrian fact finding hearings for dispositive administrative formulations. Legally, the Administrator could, within his discretion, prepare and issue definitive regulations binding without recourse, except in the courts, upon the persons involved. An examination of the regulations shows that the method adopted has been open and flexible, relying heavily upon a continuous hearing procedure not required by law, but effectuating the administrative policy that regulatory definition be slow and cautious where economic effect is unmeasured.

With one exception, ${ }^{77}$ employers and others affected are afforded an opportunity to petition the Administrator to revise the terms of the regulations. ${ }^{78}$ An opportunity is afforded to prepare a written statement setting forth changes and the reasons for such changes. If reasonable cause is set forth, the Administrator will, after notice, schedule a hearing. Upon findings made at the hearing, the regulations may be revised. An instance of such revision was a favorable action upon the petition of The Cigar Manufacturers Association of America, Inc., et al., as to the regulations defining "area of production." A petition to revise the regulations applicable to the employment of messengers was, on the other hand, refused after a hearing asked by a number of telegraph companies. ${ }^{80}$ Like the interpretative bulletins, the administrative policy of hearings to amend regulations upon petition of private persons, is a departure from the customary practice of administrative agencies.

Another outstanding procedural device employed in the regulations is review by the Administrator of the action of his authorized representative. ${ }^{81}$ In the event that the Administrator has authorized a representative to preside at a hearing of a matter pertaining, for example, to the granting or denial of a certificate of employment of an apprentice, a learner, or a handicapped worker ${ }^{82}$ (certificates which would permit the employment of persons at substandard wages), a type of administrative appeal is available at which the Administrator in person presides. ${ }^{83}$ Two full hearings are made available unless the petition for review is denied. ${ }^{84}$

Variations are found in the administrative procedure contained in the regulations. The procedure is adjusted to the particular needs of the regulation. In the regulations

${ }^{77} 29$ Code Fed. Reg. c. 5, pt. 526, 3 FED. Reg. 2534 (1938).

${ }^{78}$ A typical provision ( $\$ 536.3,29$ CODE FEd. REG., c. 5, pt. 536, 3 FEd. REg. 2536 (I938)): "Any interested person or association wishing a revision of the foregoing regulations may make application to the Administrator in writing to amend . . . by increasing or decreasing the maximum of employees permitted with the exemption as defined. If upon petition the Administrator believes that reasonable cause for amendment of the regulations is set forth, the Administrator will either schedule a hearing with due notice to interested parties or will take other measures for affording interested parties an opportunity to present their view either in support of or in opposition to the proposed changes."

${ }^{70}$ See 'Notice of Determination on Petitions by Cigar Manufacturers' Association of America, Inc., and sundry other parties for amendment (In respect to Puerto Rico Cigar Leaf Tobacco) of Section 536.2 of Regulations, Part 536, Defining 'Area of Production' (as used in section 13(a) (10) of the Fair Labor Standards Act)." 3 Fed. Reg. 2778 (1938). $\quad{ }^{80}$ (1938) I WAGE \& Hour ReP. 377-379.

81 Typical: $\$ 524.9,29$ CODE FEd. REG. C. 5, pt. 524, 3 FED. REg. 2485 (I938).

${ }^{82}$ Ibid.

${ }^{83}$ Ibid.

s. Ibid. 
pertaining to determination of reasonable cost of board, lodging and other facilities, ${ }^{85}$ for example, hearings may be had either upon notice by the Administrator or his duly authorized representative, upon the application of employees, or groups of employees, or upon the application of the employer for the purpose of making particular determinations as to any given employer. ${ }^{86}$ A general determination of "reasonable cost" under Section $3(\mathrm{~m})$ of the Act is provided in the regulations. ${ }^{87}$ A new type of notice is provided: notice from employer to employee. The hearing place is fixed near the employer's business.

In certain hearings, the regulations relate to the bringing in of witnesses by the Administrator and to matters of burden of proof. As to the latter, in the regulations applicable to the employment of messengers, ${ }^{88}$ there is a burden of proof placed upon the applicant to show that application of the minimum wage to messengers will result in curtailment of employment opportunities.

In the case of regulations applicable to industries of a "seasonal nature," an interesting administrative procedure has been devised. If, at the hearing, the Administrator or his authorized representative makes a preliminary determination that the applicant has established a prima facie case for the granting of an exemption and such prima facie case has not been opposed, the preliminary determination is published in the Federal Register. For fifteen days after publication, the Administrator stands ready to receive objection to the granting of an exemption. If such objections are received, together with a request for hearing, the matter will be set for hearing. If no objection is received and there is no request for a hearing, a finding on the prima facie case is made and the exemption becomes effective upon publication of the finding in the Federal Register.90

The manner of conducting hearings and the basis of determining findings are not formally prescribed. A species of administrative due process has been devised to meet the exigencies of the hearings. ${ }^{91}$ In the conduct of hearings by the Hearing and Exemption Section, for example, attorneys for applicants appear as witnesses, not as special pleaders. A member of the administrative staff acts as presiding officer, with the assistance of such economic, legal and enforcement experts as are deemed necessary. Cross examination is not permitted; but questions may be asked through the presiding officer. A full transcript of the proceedings is taken. The experts introduce their own statements in the record and participate in the questioning. The rules of evidence do not apply. The presiding officer makes his findings on what he believes to be material. Briefs may be filed.

The basis for determining findings is empiric, growing out of the purpose of the hearing and the purport of the testimony. In the first formal hearing by the Hearing

${ }^{85} 29$ CODE Fed. Reg. c. 5, pt. 53r, 3 Fed. Reg. 2535: (1938).

${ }^{80}$ Id. \$53I.2.

${ }^{88}$ Cf. $\$ \$ 522.7,523.7,29$ CODE FED. REG. c. 5, pt. 522, 3 Fed. REG. 2484,2485 (I938).

${ }^{80} 29$ Code Fed. Reg. c. 5; pt. 526, 3 Fed. REg. 2534 (1938) (as amended).

${ }^{90} \mathrm{Id} . \$ 526.5$.

${ }^{2 x}$ Based on interview with Chief, Hearings and Exemption Section, Wage and Hour Division; $c f$. (1938) I WAGE \& HoUR RER. 66; id. at 382; 2 id. at 42 . 
and Exemption Section, on an application to employ learners, textile industries petitioned that they be permitted to employ learners on the basis of four per cent of the total employment for a period of nine weeks at 70 per cent of the minimum wage. ${ }^{92}$ The criteria administratively prescribed for determining findings were: (a) did the industries already have a class of learner employees; (b) was such a classification necessary; (c) how long did it take a learner to become proficient; (d) what was the present approximate pay of learners; (e) what regulations were needed. The petition was voluntarily withdrawn ${ }^{93}$ after the evidence failed to show a need for a learner classification in the industry.

Phrases such as "seasonal nature," "reasonable cost" and "area of production" have no precise content. Mere application of the rules of statutory construction to such phrases could scarcely permit the divergence of definition necessary to comprise the divers industries intended to be regulated. While it is clear that the Administrator could have issued controlling definitions at the outset, he adopted a careful and precise fact finding procedure for meeting the specific problems of specific industries. The value of elaborate hearing procedures is, however, dependent in large measure upon the administrative organization, which, if understaffed, can scarcely afford to divorce from other important activities of administration and enforcement sufficient time and personnel to allow the granting of continuous hearings. A safeguard is contained in that reasonable cause must be set forth ${ }^{94}$ and reasonable cause is a matter for the judgment of the Administrator in a manner somewhat parallel to the judicial writ of certiorari. There must also be considered the cost to small industries in petitioning for amendments or revisions, or otherwise exercising rights, to have hearings in Washington as contrasted with the relative ease with which larger industries may finance the cost of hearings. Yet the slow, cautious procedure of numerous hearings preliminary to definitive regulation must, in the long run, assure realistic administration.

Problems of detection which have arisen for administrative agencies in the enforcement of unpopular laws have not yet been faced by the Wage and Hour Division. Widespread comment in the press, activity of labor organizations, and the publicity program of the Division itself have brought awareness of new rights to most of the workers affected. As a counterpart to the thousands of letters received from employers by the Division asking for interpretations of the law, thousands of complaints charging violations have been received from employees accusing employers and employers accusing competitors. By March 10, 1939, x0,712 complaints against 9,Ior establishments had been received in Washington. ${ }^{95} \mathrm{~A}$ heavy burden has been

\footnotetext{
${ }^{03}$ Notice of hearing, Nov. 9, r938; hearing commenced Nov. 28, 1938. (I938) I WAGE \& Hour REP. 36I-362, 3 FED. REG. 267I (1938).

${ }^{03}$ (I938) I WAGE \& HOUR REP. 4I8. The pressure upon the hearing procedure has been exceedingly heavy. As of April, I939, there had been over 4,500 applications for exemptions for handicapped workers alone. The Hearing and Exemption Section, with three persons available as presiding officers, had been compelled to make determinations as to validity from the face of the applications. No hearings were held.

of $C f$. $\$ 531.3,29$ CODE FED. REg. c. 5, pt. 53I, 3 FED. REg. 2535 (I938).

${ }_{0}$ Taken from summary of activities prepared by Wage and Hour Division.
} 
placed upon the Division, so great in view of the shortage of personnel that only 2,715 of these complaints had been analyzed and reviewed by middle April. ${ }^{.06}$

In order to facilitate the receipt of complaints, the Wage and Hour Division has prepared a complaint form under strict assurances that information received would be held confidential..$^{97}$ The complaint form requests information as to the nature of the business or of the establishment, identification of the complainant and a detailed statement of the exact nature of the conditions complained of. Complaints to Washington are analyzed upon receipt. They are acknowledged and further information required if they are deemed worthy of investigation. Originally, an attempt was made to adjust the matter by correspondence, and correspondence is still attempted in some cases. If correspondence fails, the case is referred to a field office in the area from which the complaint was received. The field office further investigates the charge and forwards to Washington a detailed report for legal action if deemed necessary. ${ }^{98}$

When complaints are referred to field offices they are investigated by inspectors who are under instructions to effect compliance without compulsion. The inspectors may exercise the Federal Trade Commission powers relative to the production of books, papers and documents, ${ }^{99}$ and also the specific investigatory powers. ${ }^{100}$ The Federal Trade Commission powers have been closely litigated over two decades. ${ }^{101}$ Inspectors must, in all instances, keep secret the identity of the complainant. ${ }^{102}$ They are instructed not to give interpretations of the Act. They may, however, advise employers as to ways of adjusting bookkeeping to meet the requirements of the records regulation, in pursuance of the policy that cooperation of employers should be sought rather than conviction for violation.

Investigation of complaints may take place in the course of regular inspection of books and records by the investigators, who are instructed not to divulge that complaint is one of the causes of inspection. Discovered violations of the Social Security or other federal or state laws are included in the inspector's report and he is also responsible for obtaining evidence for criminal or civil action. The subpoena power ${ }^{103}$ can be utilized only by express authority of the Administrator. In reliance upon the powers granted in Section $x(\mathrm{a}$ (a) the inspector is specifically authorized to make transcriptions of original records and to question employers. The inspector is

${ }^{80}$ Ibid.

${ }^{\circ 7}$ U. S. Dept. of Labor, Wage and Hour Division, Form CE-Io. See (1938) I WAGE \& Houn Rep. 291. The question as to whether information, documents or materials thus or otherwise obtained under pledge of confidence should be revealed on subpoena daces tecum has been litigated. In Andrews $v$. Trelles (E. D., D. of La.), Federal Judge Borah, on April 6, I939, quashed such a subpoena duces tecum on the ground that an inspector's report was confidential. The liberalized pre-trial federal practice secmed to have no effect on the privilege.

${ }^{98}$ From Enforcement of the Wage-Hour Law, address delivered at the Duke University Symposium on Law in Modern Society, Durham, N. C., Dec. 3, r938, by the Assistant Administrator in Charge of Cooperation and Enforcement, Wage and Hour Division.

${ }^{00} \$ \$ 9$ and ro of the Federal Trade Commission Act of Sept. 16, 1914, as amended, are incorporated by reference in $\$ 9$ of the Act.

${ }^{101}$ See, inter alia, Handler, The Constitutionality of Investigations by the Federal Trade Commission (I928) 28 Coc. L. Rev. 708 and 905.

${ }_{102}$ Information as to inspectors based on interview at Wage and Hour Division.

${ }^{103} \S 9$. 
not limited to investigating the records and plant of the employer but may make necessary inspection of the records of trucking companies and railroads which may have transported the goods of the employer involved.

In the initial stages of the administration and enforcement of the Act, it is probably true that the actual responsibility for complete enforcement rests with employees and labor unions. The limited appropriations available to the Wage and Hour Division make it essential that adequate machinery for the policing of the minimum standards be set up by the employees intended to be benefited. This was quickly recognized by the AFL and the CIO. Detailed interpretative bulletins were prepared explaining the rights conferred upon the employees and, in certain instances, attempting to interpret and construe the provisions of the law. ${ }^{104}$ The interpretative bulletins of the labor organizations have not always reached the same conclusions as the Office of the General Counsel of the Wage and Hour Division. ${ }^{105}$ Complaint forms have been prepared by both labor organizations. The CIO cautioned employees that "until the constitutionality of the law has been established in a suit brought by the Government, caution should be exercised in starting suits for damages on behalf of the workers. Such a suit should be brought only in clear cases, and then only after consultation with the legal department of the Congress of Industrial Organizations, or the ACWA-TWOC Wage-Hour Bureau." ${ }^{106}$ (Italics supplied.) The CIO also noted: "Workers can get the added protection of the National Labor Relations Act if, in making their complaint, they do so through the union. Any discharge on account of such complaint would then become a discharge on account of union activity." 107 The AFL warned its members: "Do not run the risk of playing into the hands of those who will try to block or circumvent the law. Be sure to consult with us before taking action." 108 In devising complaint forms, the AFL adopted a brief affidavit form providing for sworn information as to various aspects of the employer's business and of the employment relationship. ${ }^{109}$ The CIO prepared two complaint forms providing for unsworn information and for detailed facts. ${ }^{110}$

There are three types of court action available to enforce the Act: Criminal prosecution, ${ }^{111}$ civil injunction, ${ }^{112}$ and civil suit by employees or their representatives for double indemnity for unpaid compensation. ${ }^{113}$ Settlements, consent decrees, pleas of guilty with suspension of sentence upon restitution, have been favored as enforcement policy. ${ }^{114}$ The national unions have been reticent in recommending or further-

${ }^{104}$ Cf. Overtime Pay under the Wage and Hour Law, Explanatory Bulletin No. 7A, AFL (Dec. 1938).

${ }^{105}$ Id. at 4.

100 Your Rights under the Federal Wage-Four Law, Publication No. 29, CIO (April, 1939) 15.

${ }^{107} \mathrm{Id}$. at 16. CIO pecan workers on May 30, 1939 started to picket two plants allegedly in constant violation of the Act. The CIO News, May 22, I939, p. 7, col. 2.

${ }^{108}$ (1938) I WAGE \& Hour REP. 67.

${ }^{110}$ Complaint of Violations of Federal Wage-Hour Lnw, CIO.

111 \$16(a). $\quad{ }^{113} \S 16(\mathrm{a})$.

${ }^{124}$ As of May 8, 1939, the Government had taken court action in twenty-two cases, sixteen of which were suits to cnjoin employers from violating the provisions of the Act, the remainder criminal prosecutions under the penal provisions. The civil suits were brought by attorneys for the Wage and Hour Division on behalf of the Administrator as party plaintiff; criminal actions were, of course, brought on 
ing employee suits. ${ }^{115}$ As enforcement policy, it was deemed desirable that the constitutional issue, when raised, be on the strongest case. The Government is not a party to employee suits, ${ }^{118}$ but there is reason to believe that, in the beginning, the Wage and Hour Division discouraged labor union enforcement by civil suit.117

The offenses prescribed by the Act seem adequately defined. ${ }^{118}$ Outright prohibitions are provided against violation of the minimum wage or maximum hour sections, or of the provisions of any regulation or order of the Administrator relating to the exemption for learners, apprentices, messengers, and handicapped workers. ${ }^{110}$ It is not apparent why the prohibition was not extended to all regulations or orders of the Administrator. One of the proposed amendments to the Act would remedy this failure. ${ }^{120}$ The discharge of, or discrimination against, an employee because of

behalf of the United States. The first civil action was brought in the Federal District Court for the Eastern District of North Carolina on January 27, 1939, three months after the effective date of the wage and hour provisions of the Act. A consent decree was signed February 23, 1939, in which the company agreed to observe all provisions of the Act. Consent decrees were also obtained in eleven other instances in the lower Federal courts. The consent decrees provided, in one instance, for the restitution to employees of more than $\$ 2,200$ and an agreement to comply with the Act in the future; in another instance, for payment of no less than minimum wages in the future; in a third instance, for immediate conformance to the provision of the Act and the regulations thereunder and restitution of wages due for the period of noncompliance. Pending civil suits in the Federal district courts allege a variety of violations based, for the most part, upon Sections 6 and 7 of the Act. In only one instance had announcement been made that the employer would contest the constitutionality but, to date, matters of constitutionality have not been litigated.

The six criminal proceedings were brought by the Department of Justice. In four instances the defendants entered pleas of guilty; one, not guilty; one, not yet arraigned. Charges alleged pertained, usually, to violations of Section 6, falsification of records, transportation of goods in interstate commerce manufactured in violation of the Act, and failure to keep proper records of employment. The basis of the choice of criminal prosecution rather than injunction seems to have been, if the first six prosecutions are to be taken as evidence of policy, the actual falsification of records as distinguished from the failure to kecp records, and the flagrantly wilful transportation in interstate commerce of goods knowingly produced at less than the minimum wage. On pleas of guilty the defendants, in one instance, were fincd $\$ 1,000$ on each count, with suspended sentence in all but one of the counts, after promise that restitution to employees would be made; in another instance, $\$ 6,000$ of an $\$ 8,000$ fine imposed was suspended on the promise of the defendant to make restitution; in a third instance, fines of $\$ 1,000$ upon the company and $\$ 250$ each upon' the officers were entered. In a fourth case involving a five-count indictment followed by a plea of guilty, fines of $\$ 3,000$ were imposed on each count, of which $\$ 12,000$ was suspended upon stipulation that restitution totalling approximately $\$ \mathrm{I}, 700$ would be made to employees. The defendant was placed on probation for three months, during which restitution was to be made.

Files of the NRA Records Section, U. S. Department of Commerce, show that at least six of the violators sued or prosecuted had long records of complaints of violation of wage and hour standards under NRA codes.

${ }^{215}$ An examination of newspaper reports indicates that as of April 15, 1939, some twenty-five civil employee suits had been fled in various parts of the country, many without prior knowledge of national unions.

${ }^{118}$ The United States may, of course, intervene as a defendant if the constitutionality of the Act is involved. 50 STAT. 75 I (1937), 28 U. S. C. \$40I (Supp. IV, 1938).

127 "At a press conference, Mr. Andrews announced that he had received assurances from leaders of both AFL and CIO unions that they would attempt to dissuade their members from hasty court actions against employers." (1938) I WAGE \& Hour REP. r. Indications are that this policy has changed with Mulford v. Smith, decided by the Supreme Court of the United States on April 17, 1939, sustaining penal provisions upon the movement of goods in interstate commerce under quotas fixed pursuant to the Agricultural Adjustment Act of 1938 . This decision is believed to place the Act on a "firm constitutional basis." (Statement by Associate General Counsel of Wage and Hour Division at press conference, April II, I939.)

218 \$5.

${ }^{110} \mathrm{SI}_{5}(\mathrm{a})(2)$.

${ }^{120}$ See infra note 145. 
the filing of a complaint or other like behavior is made an offense. ${ }^{121}$ Violation of the records provision, or the making or keeping of false records, is prohibited. ${ }^{122}$ A "hot goods" clause prohibits the transportation, movement or sale of goods in interstate commerce, knowing such goods to have been produced in violation of the labor standards, or in violation of a regulation or order of the Administrator relating to learners, apprentices, messengers and handicapped workers. ${ }^{123}$ The latter provision is designed to avoid the competitive advantage which an employer purchasing or obtaining goods already made, may obtain over an employer producing goods for sale; but seems defective for enforcement purposes in that there is no express provision that the burden of proof that the owner had no knowledge of the violation of the law at the time he received the goods be upon such owner. Nevertheless, purchasers are loath to assume the risk of goods being "hot."124 On the whole, it is premature to judge the effectiveness of the offenses prescribed in view of the paucity of litigation thus far.

The remedies available have been partially detailed in connection with the discussion of the roles played by various agencies in connection with the enforcement of the Act. It is worthy of note that Section $\mathrm{r} 8$ contains language relative to compliance which has aroused considerable debate. Section I8 provides in part:

... No provision of this Act shall justify any employer in reducing a wage paid by him which is in excess of the applicable minimum wage under this Act, or justify an employer in increasing hours of employment maintained by him which are shorter than the maximum hours applicable under this Act."

There is no language making this clause specifically enforceable. The word "justify" carries no legal sanctions. Yet, it is apparent that language of Congress should not be construed to be meaningless. It remains to be seen whether an injunction proceeding could allege, as a count, the provision of Section $\mathrm{r} 8$ and attempt to enforce against the employer restraint against lowering his wages or increasing his hours within and not below the minimum and maximum provisions of the Act. In the case of maximum hours, the overtime compensation provision of Section 7 (a) is based upon "the regular rate" of employment. "Regular rate" may possibly be construed to include regular number of hours. This would furnish an approach alternative to Section 18.

Employee suit for double indemnity ${ }^{125}$ is potentially the most important penal provision of the Act. ${ }^{128}$ The provision lacks, however, an element contained in the

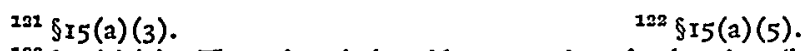

${ }^{123}$ IIS(a)(I). The prima facie evidence proviso of subsection (b) is effective but seems narrow in scope. The "hot goods" provision has been invoked a number of times, the proceedings culminating in consent decrees permanently prohibiting shipment of specified goods out of the state.

126 Especially is this true in a buyer's market where more than one manufacturer competes for the wholesaler's business. Quaere whether filing of suit by the Administrator or by an employee, or criminal charges by the Department of Justice, against a manufacturer is constructive notice to the prospective purchaser that the manufacturer's goods are "hot" within the "knowledge" proviso of §15(a)(I).

136 §I6(b).

${ }^{120}$ The employee may file individually or for a class, or through a representative, in any court of competent jurisdiction (which presumably includes state courts). The employee has a claim until the Statute of Limitations expires. He may wait until he ceases to be an employee and file, if he is loath to file suit against his employer while still cmployed. Double damages, plus reasonable attorney's fees, plus 
National Labor Relations Act designed to assure immediate relief. Suits brought in the federal courts by the National Labor Relations Board to enforce its orders are by law given precedence over all other suits on the docket. ${ }^{127}$ A like provision is not contained in the double indemnity provision of the Act. It may be questioned whether an amendment to the Act providing precedence for employee suits would prove effective. Criticism of the National Labor Relations Act provision has been made on the ground that actual experience has not proven that quick determinations are made. ${ }^{128}$ Possibility of delay is not removed. The National Labor Relations Board has had, in certain instances, to wait from one to two years for determination of suits. ${ }^{129}$

It is also premature to judge the probable effectiveness of the penal provisions in assuring compliance with the law. The large number of consent decrees and pleas of guilty may be attributed to two factors: First, the Act, in view of the latest decisions of the Supreme Court, seems on relatively sound constitutional ground, ${ }^{130}$ and the risk of litigating the constitutionality is not quickly assumed by employers; second, fines imposed by the judges who have presided in the criminal cases are heavy. ${ }^{131}$ The strict penal provisions seem not unjustified in view of the relatively low labor standards required by the Act.

Enough policy formulation has appeared in the administration and enforcement of the Act ${ }^{131^{2}}$ to permit an evaluation of preliminary public opinion. Without confusing public opinion and newspaper reaction, it is important, in connection with the Act, to consult editorial opinion. A predominantly anti-New Deal press has reacted consistently in its condemnation of the administration and enforcement of the companion National Labor Relations Act. The same press has praised, with virtual unanimity, the administration and enforcement of the Fair Labor Standards Act, and often, where opposed to wage and hour legislation, has been careful to support the Administrator. It may be noted, also, that the press has objected strenuously to certain provisions of the Act and the Administrator has recommended amendments to meet the objections. Four hundred and twenty-eight newspapers in the United

costs of the action, is, like the triple damage feature of the Sherman Anti-Trust Law, effective becausc costly.

${ }^{127}$ Section ro(i) of the National Labor Relations Act provides that petitions filed in any Circuit Court of Appeals by the Board or a party "shall be heard expeditiously" and if possible within ten days after they have been docketed."

${ }^{128}$ Cf. Wolf, Administrative Procedure Before the National Labor Relations Board (1938) 5 U. or CHI. L. REv. 358 .

${ }^{120} \mathrm{Id}$. at 380 .

${ }_{130}$ The constitutional issues raised by the Act are discussed elsewhere in this issue. See note 117, stipra. ${ }^{131}$ See note $\mathrm{ri4}_{4}$, supra.

${ }^{131 a}$ The Administrator has expressed his basic policy as to administration and enforcement of the Act as being "the principle of gradualness." Andrews, Making the Wage-Hour Latv Work (1939) 29 Ax. LAB. Leg. Rev. 53. "As with many other economic problems successful treatment depends very largely upon correct timing. While the actual employment of equal numbers at higher wages and shorter hours would be bound to have a beneficial effect on our national economy, the essential question is how rapidly this object can be attempted. Every payment to labor represents at once a source of purchasing power and an element of cost. Purchasing power can be expanded if the increase in labor cost is applied with sufficient gradualness to prevent serious economic dislocation. This principle of gradualness is essential to any important reform of labor conditions, and is the more essential when power is exercised, as it should be, over the entire national economy at one time." Id. at 58 . Cf. notes 5 and 15I, supra. 
States were examined by the writer for the period January I, I939 to April I5, r939, for the purpose of evaluating editorial reaction to the administration and enforcement of the Act. Two hundred forty-six editorials on wage and hour administration and enforcement appeared. Of 85 editorials which commented upon the policies, methods and competence of the Administrator, 76 were favorable and 9 were unfavorable. ${ }^{132}$ Thirty-six editorials were unfavorable to the overtime provisions, the largest and most vigorous single item of attack upon the Act. Of 66 editorials which commented upon the Act in general, its philosophy, or its effect upon the national economy, 34 were unfavorable to the Act and 32 noncommittal or partially favorable. On the press returns, the Administrator has scored a startling personal victory over the Fair Labor Standards Act.

As the 76 th Congress moves on, the Committee on Labor of the House of Representatives, at the time of this writing, has reported favorably a series of amendments to the Act. ${ }^{133}$ Designed to obviate such employer criticism as there has been of the administration and enforcement of the Act, the amendments, for the most part, restrict the applicability of the legislation. Most of the proposed amendments are supported, in substance, by the Administrator. ${ }^{134}$ As to some 16 categories of agricultural processing, one and one-half times the regular rate for overtime would be restricted to employment in excess of 60 hours in any work-week, ${ }^{135}$ or completely eliminated for not more than $\mathrm{I}_{4}$ work-weeks in any calendar year. Automatic application of the Act to Puerto Rico and the Virgin Islands would be superseded under an all-industries committee authorized to fix minimum wages at lower than 25 cents an hour. ${ }^{136}$ The rule-making power contained in the original bill, and not enacted, would be revived and, with certain changes, included in the Act. ${ }^{137}$ The overtime provision would not apply to employees on a guaranteed monthly basis of $\$ 200$ or more. ${ }^{138}$ Switchboard operators employed in a public telephone exchange with less than five hundred stations, ${ }^{139}$ employees employed in the ginning of cotton, ${ }^{140}$ and other processing employees, ${ }^{141}$ would be totally exempt. Exemption would be further broadened by including an hour's exemption for employees of refrigerator car companies, etc. ${ }^{142}$ Pressure to exempt telegraph messengers ${ }^{143}$ and

${ }^{133}$ Unfavorable to the Administrator: Chicago Daily News, Jan. 7, 1939; Macon (Ga.) Telegraph, Jan. 9, 1939; Beaumont (Tex.) Enterprise, Jan. II, I939; Johnstown (Pa.) Democrat, Jan. I4, I939; Montgomery (Ala.) Advertiser, Feb. 6, 1939; St. Joseph (Mo.) Gazette, Feb. I7, I939; Baltimore Evening Sun, March 17, 1939; Chicago Journal of Commerce, April 8, 1939; Richmond Times-Dispatch, April 10, 1939.

${ }^{133}$ H. R. 5435, 76th Cong., Ist Sess. (1939).

136 "Section 4(d) of the Fair Labor Standards Act of 1938, requires that the Administrator submit annually a report on activities for the preceding year and including such recommendations for further legislation in connection with minimum wage and maximum hour legislation, as in his opinion are desirable. Acting in accordance under this requirement the Administrator did, in January of this year, submit his report to Congress, together with suggestions for amendments to the Act which, in his opinion, were necessary to relieve hardship found to exist and to make the administration of the Act more effective. These suggestions were incorporated in the bill (H. R. 5436) introduced by the chairman of the committee and have been fully considered by the committee. All of them are carried in the committee amendment but not all in the form recommended by the Administrator." REP. No. 522, to accompany H. R. 5435, 76th Cong., Ist Sess. (1939) 5. ${ }_{130}$ Id. \$1.

${ }^{108}$ Id. $\$ 5$.

${ }^{141}$ lbid.

${ }^{135}$ Id. $\$ 3$.

${ }^{137}$ Id. $\$ 4$. See note 73, supra.

${ }^{230}$ Ibid.

${ }^{142} I d . \$ 6$.
160 Ibid.

${ }^{143}$ Id. $\$ 7$. 
homeworkers in rural areas ${ }^{144}$ is reflected in proposed amendments to permit the Administrator to issue regulations or orders providing for employment at lower than the minimum wage, but not less than 25 cents an hour in the case of messengers. Enforcement would be strengthened by extending the prohibition against violation of the regulations, now limited to regulations relative to learners, apprentices, messengers, and handicapped workers, to all regulations. ${ }^{14 \tilde{5}}$ Enforcement would be curtailed by a provision exempting from the "hot goods" prohibition persons having no knowledge or reason to believe that, at the time of acquiring a "property interest" therein, they were in fact "hot goods." ${ }^{46}$ A procedural amendment contains a venue provision permitting the serving of process and the bringing of suit wherever the "defendant may be found" or "is an inhabitant or transacts business"147 and would preclude assessment of costs against the Administrator in any proceeding under the Act. ${ }^{148}$ The transportation of prison labor goods in interstate commerce would be forbidden. ${ }^{149}$

The proposed amendments are, in the judgment of the CIO, in practically every case "for the benefit of the employers" constituting

"an attempt to meet claimed cases of hardship on the part of employers. There is no attempt made by these amendments to strengthen certain provisions of the Wage Hour law necessary to secure for the workers the protection which the law purportedly confers upon them."150

In no instance do they meet the following labor objections to the Act: ${ }^{\mathbf{1 5 1}}$

the too low initial minimum wage rate of twenty-five cents an hour; the too high initial maximum weekly forty-four hour level; the absence of a daily limitation on the hours of work; the absence of a specific and enforceable provision that the same weekly wage be maintained when weekly hours are shortened; the vague and confused language of Section 7 (b) relating to maximum hours under collective bargaining agreements; the numerous, unjustified exemptions under Section 7 (c); the permission to employ apprentices, learners and messengers at substandard minimum wages, contained in Section I4; the authorization to industry committees to establish wage classifications within an industry; the absolute discretion left to the Administrator to disapprove recommendations of industry committees under Section 8(d); the absence of language which would give precedence to employees' suits for back wages and otherwise to expedite such suits; the failure to make specifically enforceable the provisions of Section 18 that no provision of the Act shall "justify" an employer in reducing a wage paid by him or in increasing hours of employment maintained by him.

$1+1$ Ibid.

${ }^{147}$ Id. $\$ \mathrm{II}$.

${ }^{160}$ (1939) 2 WAGE \& HOUR REP. 183.

${ }^{145} \mathrm{Id} . \S 8$.

${ }^{148} \mathrm{Ibid}$.

${ }^{161}$ See address delivered by Boris Shishkin, Economist, American Federation of Labor, before annual meeting of the American Association for Labor Legislation, Detroit, Michigan, Dec. 29, 1938. (1939) 2 WAGE \& Hour ReP. 5 and Wage-Hour Law Administration from Labor's Viewpoint (I939) 29 AM. LAB. LEGIS. REv. 63, 65. "At the end of six months of practical administration of the Act it may be fair to summarize Labor's view that the administration of the law has shown overanxiety about employers' welfare and relative inattention to expressions of the workers' real needs." Id. at 64 ; cf. notes 13 Ia and 5 , stupra. 